\title{
Combining tracer studies and biomimetic design principles to investigate clogging in constructed wetlands
}

\author{
Ricky Bonner ${ }^{1,2}$, Lara Aylward ${ }^{1,2}$, Uwe Kappelmeyer ${ }^{3}$ and Craig Sheridan ${ }^{1,2 *}$ \\ 'Industrial and Mining Water Research Unit, School of Chemical \& Metallurgical Engineering University of the Witwatersrand, \\ Johannesburg, 1 Jan Smuts Avenue, Braamfontein, 2000, Johannesburg, South Africa \\ ${ }^{2}$ Centre in Water Research and Development, University of the Witwatersrand, Johannesburg, 1 Jan Smuts Avenue, \\ Braamfontein, 2000, Johannesburg, South Africa \\ ${ }^{3}$ Helmholtz Zentrum für Umweltforschung UFZ, Leipzig-Halle, Dept. of Environmental Biotechnology, \\ Permoserstraße 15, D-04318 Leipzig, Germany
}

\begin{abstract}
In this study, we suggest a clogging maintenance strategy and design alteration for constructed wetlands. Such a system could benefit rural communities who rely solely on constructed wetland systems for provision of household and agricultural water and for whom regular system shut-down for maintenance is essentially not viable. A newly established, pilot-scale horizontal subsurface flow constructed wetland was investigated by means of step-change tracer experiments. Sampling was carried out at multiple points down the length of the wetland and at three depths for each location. The mean residence time data were used to generate velocity profiles. This methodology enabled the development of a three-dimensional hydraulic model to identify dead zones and regions of short-circuiting within the system. Biomimetic principles were then incorporated to propose improvements to conventional constructed wetland design, which would potentially allow for better clogging management and continuous operation. In particular, modularizing the regions of the wetland most prone to clogging (those containing dead space) would accommodate isolation, removal and replacement of such sections, while still allowing treatment of wastewater in adjacent sections.
\end{abstract}

Keywords: wastewater treatment, step-change tracer study, velocity profiles, constructed wetland, clogging, biomimicry

\section{INTRODUCTION}

\section{Background}

South Africa faces a number of serious water supply and quality challenges (Hedden and Cilliers, 2014). The development and implementation of water treatment technology is, thus, of utmost importance. To this end, the national government provides financial support for the improvement of water infrastructure (Tibane and Vermeulen, 2013) and the Department of Science and Technology (DST) has defined specific projects to support the work around the development of the country's ecological infrastructure, which was initiated by the Department of Environmental Affairs (DEA) and the South African National Biodiversity Institute (SANBI). In 2013, the then Department of Water Affairs (DWA, now the Department of Water and Sanitation) laid out a strategic plan to address the water challenges which the country faces. The plan cites skills development and the improvement of infrastructure as two main areas to be targeted and views water as a catalyst to the future development of the country (Tibane and Vermeulen, 2013).

One of the main challenges in a South African context is to develop infrastructure that allows for easy and reliable access to clean water for rural communities (Majuru et al., 2012). Horizontal subsurface flow constructed wetlands (HSSF CWs) are an attractive solution to the problem and their applicability is currently being explored (Ochieng et al., 2010). HSSF CWs

\footnotetext{
To whom all correspondence should be addressed.

盛 +2711717 7592

e-mail: craig.sheridan@wits.ac.za
}

Received 10 July 2017, accepted in revised form 5 October 2018 are complex ecosystems which lie intermediate between terrestrial and aquatic environments (Stottmeister et al., 2003). Such systems typically contain a solid matrix, macrophytes and bacteria which work as a functional unit to improve the quality of water (Galletti et al., 2010, Marchand et al., 2010). Physical, chemical and biological water treatment processes are thus combined into a single unit and require minimal human input for sustenance, thus providing a low-capital and lowmaintenance alternative to traditional treatment technologies (Saeed and Sun, 2012). These systems are capable of treating many different types of wastewater to make it suitable for re-use (Vymazal, 2009). Examples include, among others, domestic sewage (Mantovi et al., 2003), stormwater run-off (Maillard et al., 2011) and agricultural run-off (Stehle et al., 2011).

\section{Effect of hydraulic behaviour on treatment performance}

Effective treatment in constructed wetlands requires wastewater to reside inside the system for a long enough period of time for pollutants to be transformed or degraded (Kantawanichkul et al., 2009). The residence time of fluid within the system is a function of flow rate and flow path, the latter being determined by the dynamic physical structure of the wetland. Researchers have shown that plant root development, bacterial biofilm growth, suspended solids accumulation and metal precipitation cause clogging within the gravel bed (Knowles et al., 2011; Pedescoll et al., 2011), rendering certain sections of the system inaccessible to the wastewater passing through. The fluid will naturally find the path of least resistance through other regions of the wetland to create a short-circuiting effect and, hence, a reduction in treatment efficiency (Min and Wise, 2009). 
Fluid flow behaviour can be examined by conducting hydraulic tracer studies on the system (Alcocer et al., 2012). An inert chemical dye is injected at the wetland inlet, either as a single pulse or a step-change in feed concentration, and the concentration of the dye is continuously measured at various points within the system and at the outlet (Sheridan et al., 2014b; Suliman et al., 2006). Numerical techniques are then used to evaluate important hydraulic parameters; namely, the fractional tracer recovery, mean fluid residence time, tracer spread and various hydraulic efficiency indices which are a metric of treatment efficiency. The residence time distribution can ultimately assist in producing estimates of the velocity profiles inside the system.

\section{Sub-surface clogging management strategies}

Different management strategies have been developed to remediate the effects of clogging inside HSSF CWs. Two of the most frequently used are excavation and washing of the bed media, but in-situ application of cleaning chemicals, such as hydrogen peroxide, has also been reported in the literature (Nivala et al., 2012). Dotro et al. (2011) note, however, that excavation and washing requires the system to be taken offline for extended periods of time. In-situ application of cleaning chemicals poses health and safety risks to local community members and the long-term effects of the chemicals on wetland performance are still unknown (Nivala and Rousseau, 2009).

\section{Biomimicry and wetland clogging management}

The application of biomimicry in the field of CW design is receiving attention from both designers and researchers (Kenny et al., 2012; Van Vuuren, 2014). Biomimicry can be classified as an applied science which involves the careful study of nature's systems, designs and processes to find solutions to human problems (El-Zeiny, 2012). The biomimicry design lens, presented in Fig. 1, provides

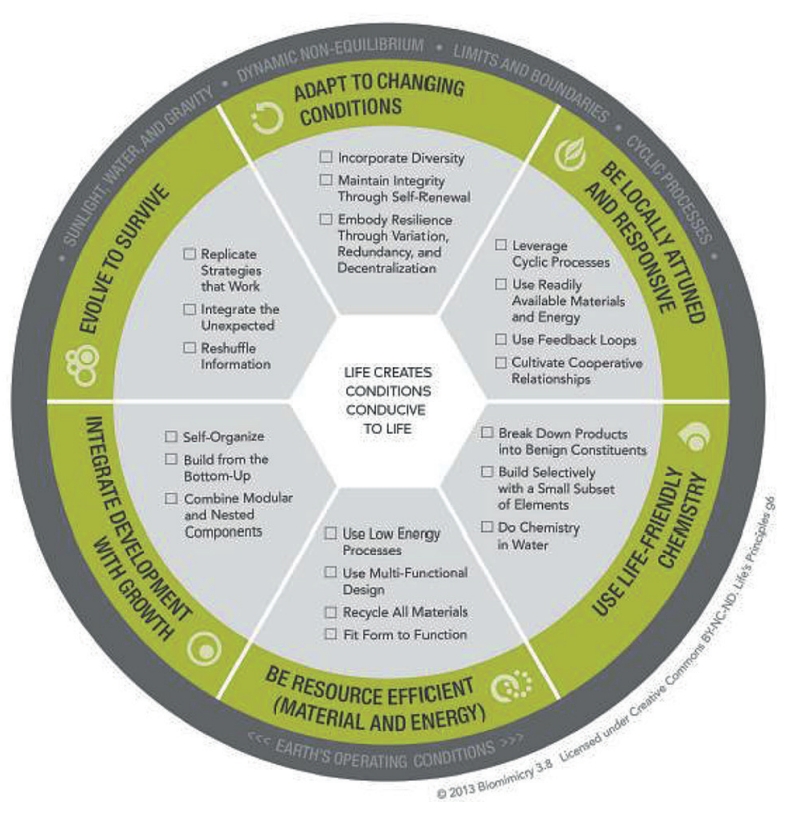

Figure 1

'The Biomimicry Design Lens' by Biomimicry 3.8 (https://biomimicry.net/ the-buzz/resources/biomimicry-designlens/) used under CC BY-NC-ND a set of principles with which sustainable system design may be achieved (Kennedy et al., 2015). Two principles, in particular, may be useful for the purposes of wetland clogging management. Firstly, natural systems are able to "adapt to changing conditions" (see Fig. 1 top segment). According to the design lens (Fig. 1), this includes an ability to "embody resilience through variation, redundancy and decentralization". This attribute of natural systems is appropriate to clogging management since it advocates maintaining function following a disturbance by incorporating a variety of duplicate forms, processes or systems that are not located exclusively together. Secondly, natural systems show, on numerous occasions, how they are able to "integrate development with growth" and "combine modular and nested components". Based on these basic principles, a set of modified CW designs, which limit the effect the adverse effect of clogging on treatment efficiency, could be proposed. As an example, CWs could be modularized or divided into smaller sub-sections, as indicated in Fig. 2. Should a section of the wetland become clogged to the extent that hydraulic conductivity is dramatically reduced, this design allows for the clogged sub-section to be isolated and flow allowed made to by-pass it. Hence, operation and maintenance can be carried out simultaneously. For rural communities, whose sole source of water may be a CW, continual treatment and supply of wastewater is a necessity.

\section{Research objectives}

In this paper, we illustrate how hydraulic tracer studies can be coupled with biomimetic design principles to suggest modifications to the design of an existing HSSF CW for the purposes of improved clogging management and, ultimately, more consistent treatment performance. The aim of the paper is two-fold:

- Identifying regions most prone to clogging by conducting hydraulic tracer studies and estimating velocity profiles

- Using biomimetic design principles (modularity and decentralization) to modify system design so that clogging effects may be minimized

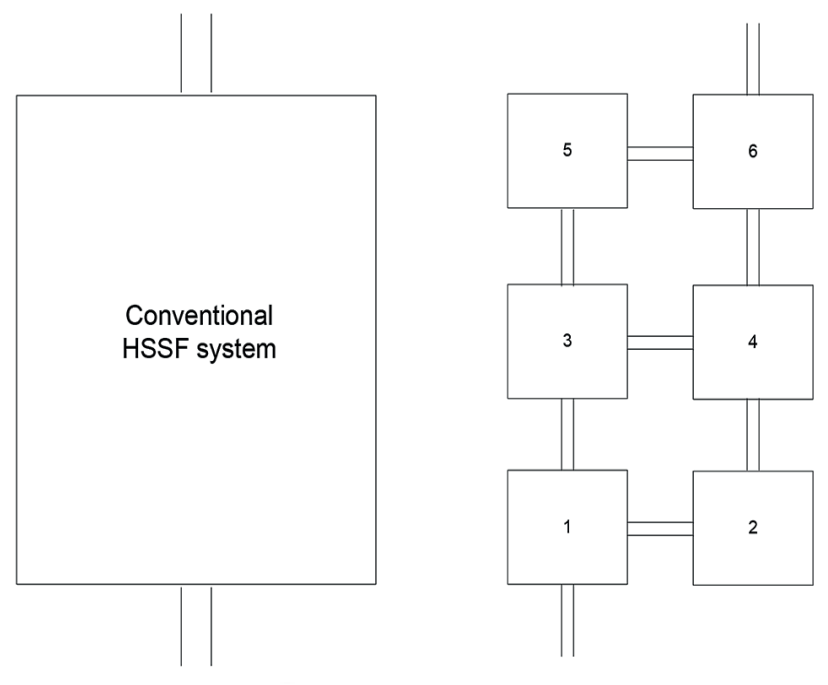

Figure 2

Conventional HSSF system (left) and modularized biomimetic HSSF system (right) 


\section{MATERIALS AND METHODS}

\section{Pilot-scale CW}

The pilot-scale CW was located at the Industrial and Mining Water Research Unit (IMWaRU) facility at the University of the Witwatersrand, Johannesburg. The system contained an HDPE external support trough, filled with dolomitic gravel, and fed by three equally spaced valves located close to the surface of the gravel bed. It also contained 13 outlet valves, from which the cumulative discharge was collected into a single outlet pipe. Further details of the inlet and outlet distribution networks can be found in the hydraulic study published by Bonner et al. (2017).

Thirteen cylindrical sample ports made from PVC mesh (mesh opening $20 \mathrm{~mm}$ ) were installed into the gravel bed and three different lengths of silicon tubing were cut and secured to the interior wall of each sampling well. This configuration allowed the system to be divided into a grid comprising 13 regions, 3 depths and 39 modules. The wetland was planted with 5 different species of indigenous wetland vegetation; each occupying one of 5 zones into which the wetland was divided. A nutrient solution containing phosphate and nitrate was added to stimulate plant growth. The plants were allowed to establish for a period of 6 weeks before the commencement of the first set of experiments (Bonner et al., 2017). Table 1 provides a summary of the $\mathrm{CW}$ design parameters. Figure 3 is an illustration of the experimental unit, while the regions inside the CW, the sample port positions and the different plant species planted within the system are shown in Fig. 4.

\section{Hydraulic data generation}

Step-change tracer studies were conducted using the fluorescent chemical tracer dye FWT Red (Cole-Parmer, USA). At the time of these initial experiments, the system had been fed with municipal tap water only. A volume of $300 \mathrm{~mL}$ of dye was injected into two $5 \mathrm{~m}^{3}$ cylindrical 'Jo-Jo' tanks filled with tap water. The contents of the two tanks were circulated continuously for $24 \mathrm{~h}$ by means of a submersible pump to ensure that $10 \mathrm{~m} 3$ of homogeneous tracer solution was available
TABLE 1

Engineering design parameters of the planted CW

\begin{tabular}{|l|r|}
\hline Parameter & Value \\
\hline Total length $(\mathrm{mm})$ & 4200 \\
\hline Total width $(\mathrm{mm})$ & 900 \\
\hline Bed height $(\mathrm{mm})$ & 700 \\
\hline Porosity $(\%)$ & 43 \\
\hline Reactor volume (excluding solids) (m3) & 1.14 \\
\hline Mean particle diameter (mm) & 20 \\
\hline Sampling depth 1 (yellow) (mm) & 50 \\
\hline Sampling depth 2 (blue) $(\mathrm{mm})$ & 350 \\
\hline Sampling depth 3 (purple) $(\mathrm{mm})$ & 680 \\
\hline
\end{tabular}

\begin{tabular}{|l|l|}
\hline Parameter & Value \\
\hline Total length (mm) & 4200 \\
\hline Total width (mm) & 900 \\
\hline Bed height (mm) & 700 \\
\hline Porosity $(\%)$ & 43 \\
\hline Reactor volume (excluding solids) $\left(\mathrm{m}^{3}\right)$ & 1.14 \\
\hline Mean particle diameter (mm) & 20 \\
\hline Sampling depth 1 (yellow) (mm) & 50 \\
\hline Sampling depth 2 (blue) (mm) & 350 \\
\hline Sampling depth 3 (purple) (mm) & 680 \\
\hline
\end{tabular}

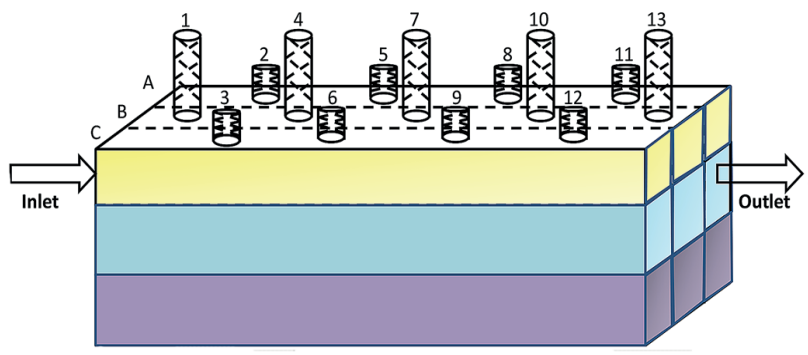

Figure 3

Schematic of the pilot-scale CW indicating the direction of flow and positions of all sampling wells

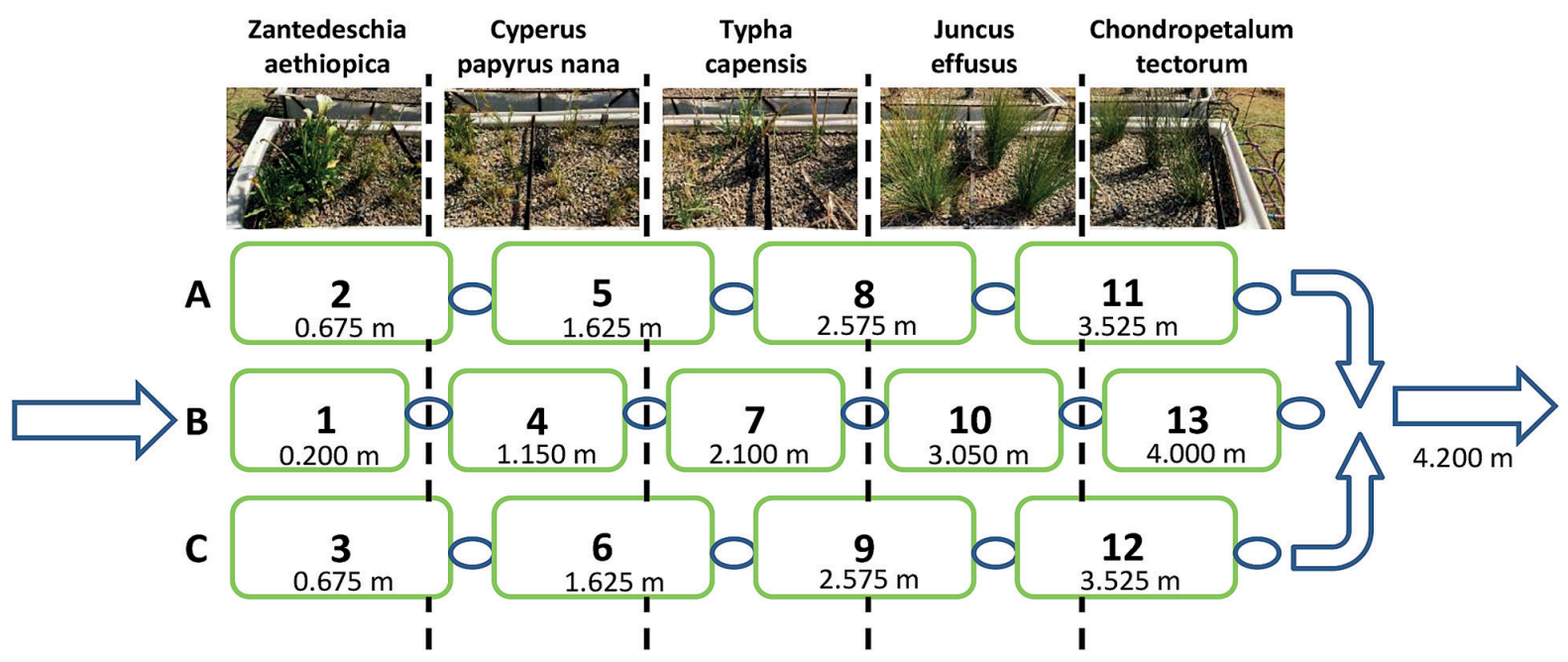

Figure 4

Different types of indigenous wetland plant species (by Zone $A, B$ and $C$ indication left, centre or right flow channel) and aerial view of the regions within the planted CW showing the longitudinal positions of the 13 sampling wells (meters from the inlet). 
for the study. The inlet and outlet flow rates were allowed to equalise, at which time the feed to the $\mathrm{CW}$ was switched from tap water to the tracer solution. Samples were taken at $30 \mathrm{~min}$ intervals from each sample port and depth for a period of 12 $h$. The inlet and outlet flow rates were monitored continuously using a flow meter (Gardena, Germany). The average flow rate (v) was calculated to be $4.13 \mathrm{~L} / \mathrm{min}$. The absorbance of each sample was measured using a Spectroquant Pharo 300 (Merck, Germany) at a wavelength of $550 \mathrm{~nm}$. Absorbance readings were converted to tracer concentration by constructing a calibration curve ( $R^{2}$ of 0.99$)$.

\section{Hydraulic modelling}

The concentration-time curve obtained for each sampling port was converted to the cumulative distribution curve using Eq. 1:

$$
F(t)=\frac{C(t)}{C_{\max }}
$$

Where $C_{\max }$ is the concentration of tracer as $t \rightarrow \infty$ and $F(t)$ is the cumulative distribution function. The mean residence time of the fluid was then determined using Eq. 2.

$$
\bar{t}_{m}=\int_{0}^{\infty}[1-F(t)] d t
$$

Eq. 2 requires numerical integration of the area below the $1-F(t)$ curve for which Simpson's $1 / 3$ rule was chosen. This method approximates the area under a parabolic curve by dividing the space into multiple, equally-sized sub-intervals and summing their areas together. The resulting formula is shown in Eq. 3.

$$
I=\frac{h}{3}\left[f\left(x_{0}\right)+4 f\left(x_{1}\right)+2 f\left(x_{2}\right)+\cdots+4 f\left(x_{n-1}\right)+f\left(x_{n}\right)\right]
$$

where:

$$
h=\frac{b-a}{n}
$$

with $n$ being the number of equally sized sub-intervals. The nominal hydraulic retention time indicates the residence time of the water inside the CW under ideal conditions (without any shortcircuiting effects) (Sheridan et al., 2011), and is provided by Eq. 5 .

$$
\tau=\frac{V_{\text {reactor }}}{\dot{v}}
$$

The ideal, or theoretical, velocity profile was determined by plotting the nominal retention time at a sampling port against its length from the inlet. The gradient of the curve was thus determined using Eq. 6:

$$
m_{\text {theoretical }}=\frac{\tau_{i+1}-\tau_{i}}{x_{i+1}-x_{i}}
$$

where the gradient represented the inverse of the magnitude of the velocity $(u)$ under ideal conditions in module $i+1$ in a specific zone and at a specific depth in the system. Similarly, the experimentally determined mean residence time at a specific sampling port was plotted against its corresponding length and the gradient determined using Eq. 7.

$$
m_{\text {experimental }}=\frac{\bar{t}_{m, i+1}-\bar{t}_{m, i}}{x_{i+1}-x_{i}}
$$

where the gradient represented the inverse of the magnitude of the estimated experimental velocity in module $I$ +1 in a specific zone and at a specific depth in the system.

The rules laid out in Table 2 were then used to identify nonideal flow behaviour within specific modules of the wetland.

\section{RESULTS AND DISCUSSION}

In Fig. $5 a-c$, the mean residence time at each sampling location is plotted against its corresponding length down the system. Detailed hydraulic results of the tracer studies can be found in Bonner et al. (2017). The black dotted line in each figure represents the curve which would be obtained under ideal conditions; that is, with no dead zones or short-circuiting effects.

In each of Zones $\mathrm{A}-\mathrm{C}$, the experimental curves deviate from the ideal curve, indicating non-ideal flow behaviour. The data in Fig. 5 were then used with the mathematical rules in Table 3 to construct Fig. 6, which provides a three-dimensional visualization of the dead spaces and areas of short-circuiting within the system under study. The nomenclature used for each module follows the rule: $X, Y$ where $X$ indicates the region (Fig. 4) and $Y$ the sampling depth: $1(5 \mathrm{~cm}), 2(35 \mathrm{~cm})$ or $3(68 \mathrm{~cm})$ below the gravel surface. The presence of dead zones in each channel (Zone A, B or C) are shown and the $t_{m}$ values being significantly greater than ideal for the $68 \mathrm{~cm}$ depth samples is emphasized by the predominantly red modules at the bottom of Fig. 6 .

Vegetative contributions to CW clogging have been discussed extensively by researchers (Knowles et al., 2011). Wetland vegetation may impact hydraulics in many ways. Dense live root penetration (Tanner, 1994) as well as stems which are physically and chemically stable due to the presence of esters in the plant tissue (Tanner et al., 1998) cause blockages in the pore spaces and present physical barriers to fluid flow. In addition, plants transfer oxygen from the atmosphere to their root zones, inducing aerobic conditions in the upper layers of the CW (Stottmeister et al., 2003). The oxidizing conditions facilitate ferric hydroxide precipitation, which creates a thick sludge in and around the plant roots and further contributes to clogging (Nivala et al., 2007).

Although the plants would not have been fully developed at

\begin{tabular}{|c|c|c|}
\hline \multicolumn{3}{|c|}{$\begin{array}{c}\text { TABLE } 2 \\
\text { Mathematical rules used to characterize hydraulics in modules inside CW }\end{array}$} \\
\hline m_experimental $=m$ _theoretical & $u \_$experimental $=u \_$theoretical & Plug (ideal) flow \\
\hline m_experimental $<m_{\text {_theretical }}$ & u_experimental $>$ u_theoretical & Channelling/short-circuiting \\
\hline m_experimental $>$ m_theoretical & $u \_$experimental $<u \_t h e o r e t i c a l$ & Dead zone/clogging \\
\hline
\end{tabular}
the time of the experiment, Fig. 4 may be used in conjunction with Fig. 6 to explain some of the non-ideal flow behaviour; particularly in the upper two layers. Upon examination of the distribution of the Zantedeschia aethiopica at the front end of the system (Fig. 4), it is seen that the vegetation is highly concentrated in Zone B with comparatively less planting along 

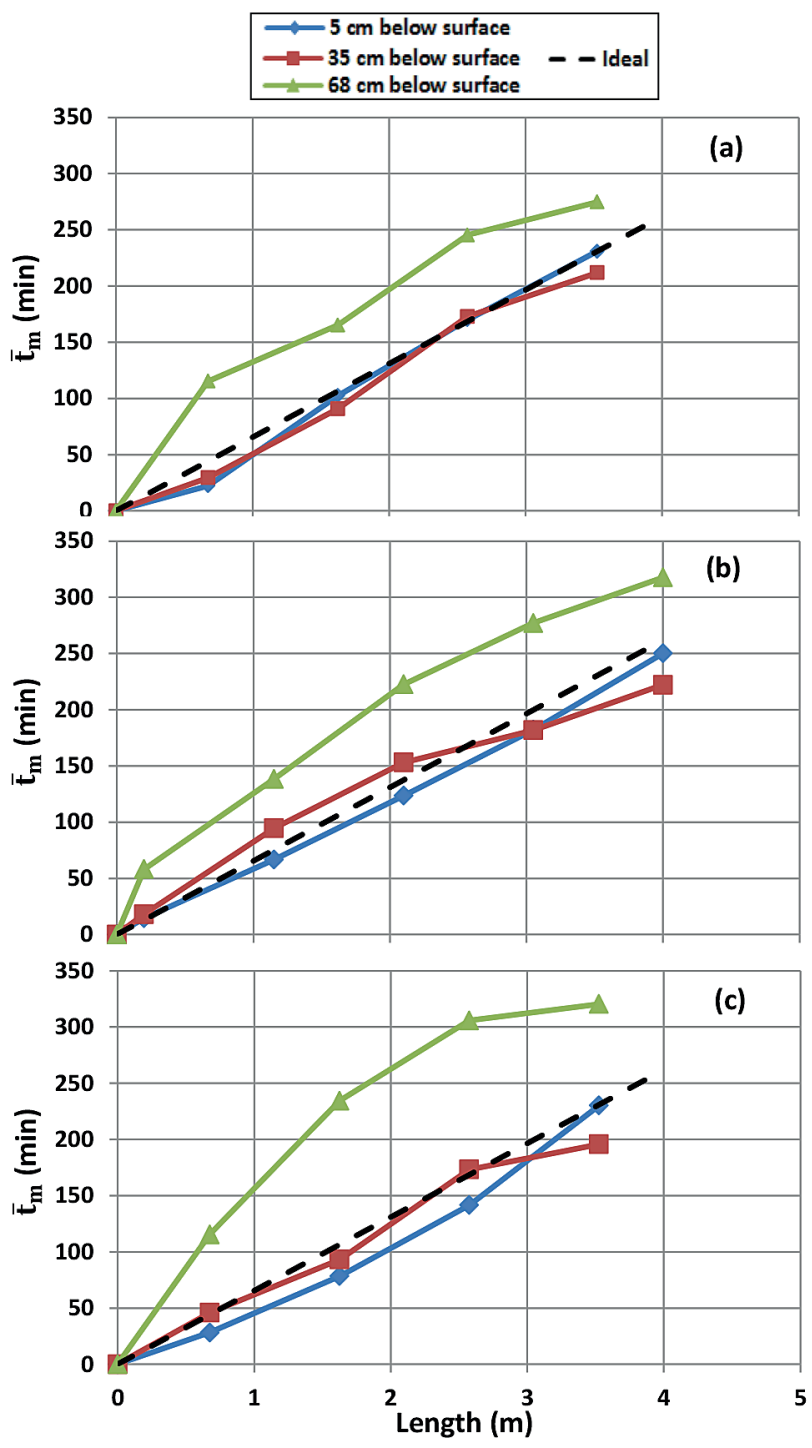

Figure 5

Mean residence time versus length down $C W$. (a) represents data collected from Zone A, (b) from Zone B and (c) from Zone C (with zones shown in Fig. 4.)

the sides in Zones A and C (Fig. 6). This may explain the dead zone found in Module 1,1 and the channelling of fluid down the sides in Modules 2,1 and 3,1 where the hydraulic conductivity is higher. A similar scenario is observed in Modules 8,1 and 8,2 as well as in 9,1 and 9,2 in which there is a relatively dense distribution of Typha capensis and Juncus effusus down the sides of the system. Zone B is more sparsely populated, resulting in higher subsurface fluid velocities in Modules 7,1 and 7,2 as well as in 10,1 and 10,2.

The presence of dead zones in the bottom layer of the system in Modules 1,3;2,3 and 3,3 may be explained by three factors. Firstly, the inlet ports to the system are situated level with the surface of the gravel; thereby inducing a hull-shaped flow profile and a large dead zone at the bottom of the system near the inlet. A similar effect was observed by other CW researchers with the same inlet manifold structure (Sheridan et al., 2014a). Low subsurface fluid velocities enhance the likelihood of sedimentation of larger suspended solids within these modules, contributing to the clogging process (Kadlec and Wallace, 2009). Bacteria then feed off the organic matter deposits; thereby assisting with proliferation and biofilm formation (Dupin et al., 2001). Biofilms are capable of secreting a polymeric slime which blocks pore spaces and prevents the passage of fluid (Knowles et al., 2011, Madigan et al., 2009). The other dead zones found in the bottom layer of the system may be due to a combination of various clogging processes, such as straining and trapping, adsorption and chemical precipitation (Knowles et al., 2011).

\section{Modification of CW design using biomimetic principles}

The hydraulic investigation showed that almost all of the 13 regions (excluding Regions 10 and 11) had a dead zone and, hence, some clogging effects in at least one of the topographical layers. In order to alleviate the effects of clogging on overall treatment performance, biomimetic design principles would suggest a more modular CW design. For instance, each region investigated here could be considered a sub-reactor and various combinations of reactors in series and parallel, as well as methods of connecting them, could be proposed. For example, isolation valves could be used, as shown in Fig. 7, so that any sub-reactor within the larger CW network could be shutoff for cleaning while the remaining units continue to treat water. It is not recommended that the regions be modularized topographically due to the construction difficulties imposed by such a task.

Top layer

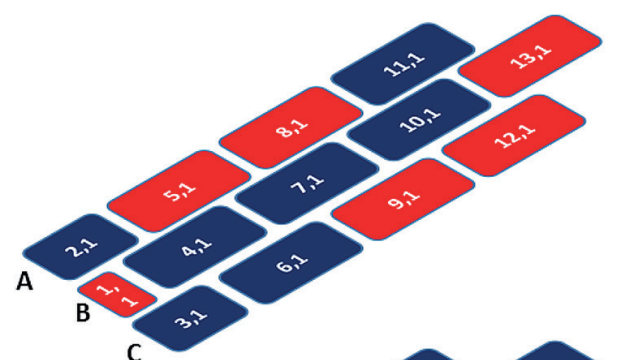

Middle layer

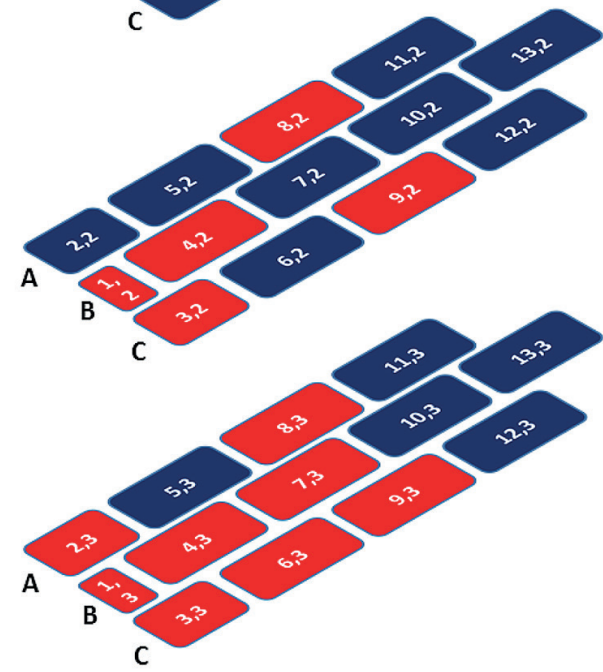

Figure 6

Three-dimensional view indicating estimates of the fluid flow behaviour within each of the three layers of the CW. Blue modules indicate regions in which channelling/short-circuiting occurred and red modules indicate regions in which dead zones existed. 
The design in Fig. 7 would require the protocols of clogging management for the system to be detailed. This should include, at least, the following information:

- The location of the valves to be opened/closed and the order in which this must be done to isolate any clogged region

- The procedure for cleaning the solid matrix within the clogged region

- The procedure for re-installing the cleaned region and returning the system to standard operating conditions

The design modification suggested in Fig. 7 is just one of many possibilities and may, for example, be further improved by the addition of a filtration/sedimentation unit as a preliminary stage. It is biomimetically inspired and offers advantages in terms of clogging management, but it is also acknowledged that it may be subject to a number of practical constraints. For instance, the inclusion of the number of valves suggested could impose high capital and maintenance costs and, if the system is implemented in a rural community as desired, the question as to what extent the community must be included and educated is still to be answered. Any such system would have to be constructed and tested experimentally to draw final conclusions about the practicality of the design in comparison to conventional CW systems and, moreover, the social aspect would require multi-disciplinary partnerships from the outset. This modification would be based on the assumption that the hydraulic loading rate was correctly designed for the system. It is possible that periodic drainage and aeration could also assist with preventing clogging (Carballeira et al., 2017), in addition to the proposed modification.

\section{CONCLUSIONS AND RECOMMENDATIONS}

This paper presents a general methodology for investigating $\mathrm{CW}$ internal flow behaviour in more detail. The method has, here, been applied to an investigation of wetland clogging and used to suggest a modularized wetland design to alleviate clogging effects. A definitive conclusion as to the general applicability of the proposed solution cannot be drawn at this stage; the aim is to propose a methodology and a different approach to CW experimental research. It is a recognised limitation, however, that this study was conducted at laboratory-scale and that the conclusion may be different at pilot- or large-scale.
Three-dimensional hydraulic modelling was performed on an existing horizontal subsurface flow constructed wetland by conducting step-change tracer studies and using the mean residence time data to estimate velocity profiles within the system. The hydraulic investigation identified dead zones and regions in which short-circuiting occurred. Biomimetic design principles were then applied to suggest modifications to the design of the system by modularizing the regions prone to clogging.

Although this is still the early design phase and the practicalities of the particular system have not yet been fully investigated, the suggested design offers definite potential in terms of allowing for different sections of the wetland to be isolated for maintenance while the rest of the system continues to treat water. The clogging management solution presented in this study is intended to benefit rural communities, in South Africa and in general, whose sole wastewater treatment facility may be a CW-type system, making shutdown of the whole facility for clogging maintenance to not be a viable option. It is hoped that the community may be fully involved in all stages of planning, construction and start-up and be able to maintain and manage such a system independently.

\section{ACKNOWLEDGEMENTS}

We wish to thank the School of Chemical and Metallurgical Engineering Workshop at the University of the Witwatersrand for their assistance with the experimental set-up. This research was supported by the Water Research Commission, South Africa, through Project K5/2096/3, entitled 'Exploring knowledge on natural processes for novel approaches to constructed wetlands design and performance for wastewater' with additional funding obtained from the South African NRF.

\section{REFERENCES}

ALCOCER DJR, VALLEJOS GG and CHAMPAGNE P (2012) Assessment of the plug flow and dead volume ratios in a subsurface horizontal-flow packed-bed reactor as a representative model of a sub-surface horizontal constructed wetland. Ecol. Eng. 40 18-26. https://doi.org/10.1016/j.ecoleng.2011.10.018

BONNER R, AYLWARD L, KAPPELMEYER U and SHERIDAN CM (2017) A comparison of three different residence time

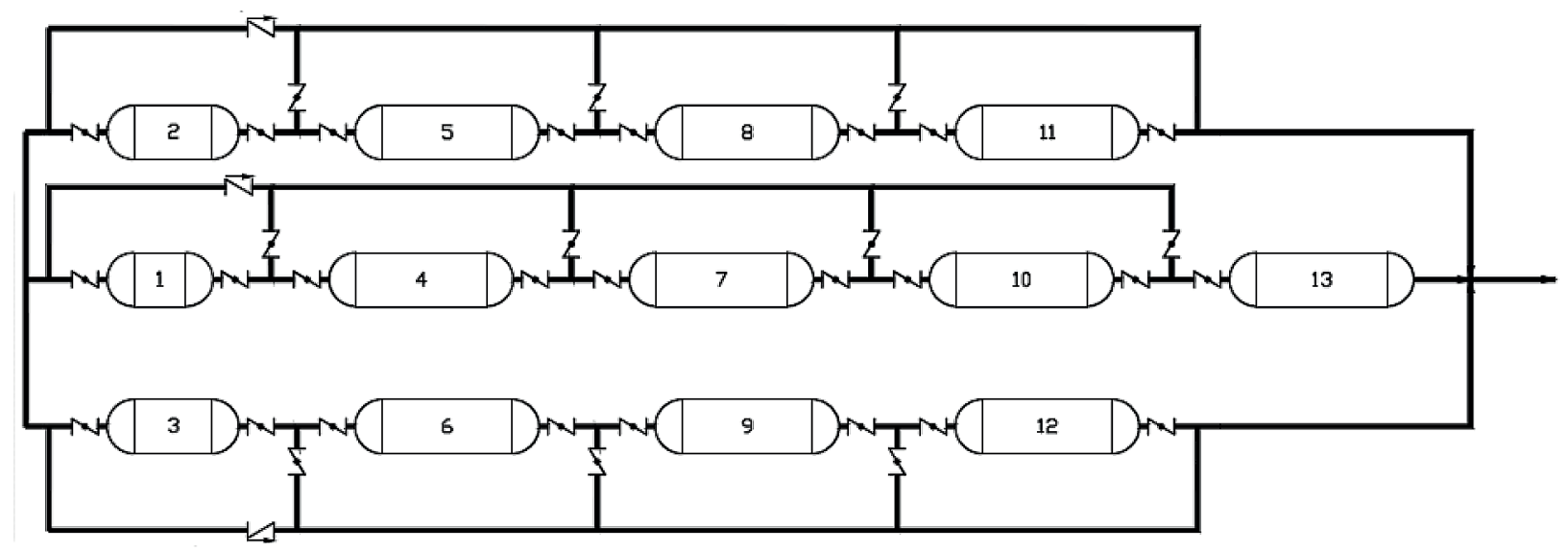

Figure 7

Plan-view of suggested biomimetic design of $C W$ based on hydraulic modelling results. Streams showing interactions between adjacent regions have not been included in the diagram due to spatial constraints. 
distribution modelling methodologies for horizontal subsurface flow constructed wetlands. Ecol. Eng. 99 99-113. https://doi. org/10.1016/j.ecoleng.2016.11.024

CARBALLEIRA T, RUIZ I and SOTO M (2017) Aerobic and anaerobic biodegradability of accumulated solids in horizontal subsurface flow constructed wetlands. Int. Biodeterior. Biodegrad. 119 396404. https://doi.org/10.1016/j.ibiod.2016.10.048

DOTRO G, GRIFFIN P, JEFFERSON B and BUTTERWORTH E (2011) Managing clogging in Severn Trent wetlands. Constructed wetland: domestic, commercial \& industrial , 14-15 July 2011, Constructed Wetland Association, Wakefield, United Kingdom.

DUPIN HJ, KITANIDIS PK and MCCARTY PL (2001) Simulations of two-dimensional modeling of biomass aggregate growth in network models. Water Resour. Res. 37 2981-2994. https://doi. org/10.1029/2001WR000310

EL-ZEINY RMA (2012) Biomimicry as a problem solving methodology in interior architecture. Procedia Soc. Behav. Sci. 50 502-512. https://doi.org/10.1016/j.sbspro.2012.08.054

GALLETTI A, VERLICCHI P and RANIERI E (2010) Removal and accumulation of $\mathrm{Cu}, \mathrm{Ni}$ and $\mathrm{Zn}$ in Horizontal subsurface flow constructed wetlands: contribution of vegetation and filling medium. Sci. Total Environ. 408 5097-5105. https://doi. org/10.1016/j.scitotenv.2010.07.045

HEDDEN S and CILLIERS J (2014) Parched prospects - the emerging water crisis in South Africa. African Futures Paper 11. Institute for Security Studies, Pretoria.

KADLEC RH and WALLACE SD (2009) Treatment Wetlands (2nd edn). CRC Press, New York.

KANTAWANICHKUL S, KLADPRASERT S and BRIX H (2009) Treatment of high-strength wastewater in tropical vertical flow constructed wetlands planted with Typha angustifolia and Cyperus involucratus. Ecol. Eng. 35 238-247. https://doi.org/10.1016/j. ecoleng.2008.06.002

KENNEDY B, BUIKEMA A and JAMES JK (2015) Integrating biology, design, and engineering for sustainable innovation. Integrated STEM Education Conference. IEEE, New Jersey, USA.

KENNY J, DESHA C, KUMAR A and HARGROVES C (2012) Using biomimicry to inform urban infrastructure design that addresses 21st Century needs. 1st International Conference on Urban Sustainability and Development, 5-6 November 2012, London. University College London, London.

KNOWLES P, DOTRO G, NIVALA J and GARCÍA J (2011) Clogging in subsurface-flow treatment wetlands: Occurrence and contributing factors. Ecol. Eng. 37 99-112. https://doi.org/10.1016/j. ecoleng.2010.08.005

MADIGAN MT, MARTINKO JM and BROCK TD (2009) Brock Mikrobiologie. Pearson Deutschland GmbH, Hallbergmoos.

MAILLARD E, PAYRAUDEAU S, FAIVRE E, GRÉGOIRE C, GANGLOFF S and IMFELD G (2011) Removal of pesticide mixtures in a stormwater wetland collecting runoff from a vineyard catchment. Sci. Total Environ. 409 2317-2324. https://doi. org/10.1016/j.scitotenv.2011.01.057

MAJURU B, JAGALS P and HUNTER PR (2012) Assessing rural small community water supply in Limpopo, South Africa: Water service benchmarks and reliability. Sci. Total Environ. 435 479-486. https:// doi.org/10.1016/j.scitotenv.2012.07.024

MANTOVI P, MARMIROLI M, MAESTRI E, TAGLIAVINI S, PICCININI S and MARMIROLI N (2003) Application of a horizontal subsurface flow constructed wetland on treatment of dairy parlor wastewater. Bioresour. Technol. 88 85-94. https://doi. org/10.1016/S0960-8524(02)00291-2

MARCHAND L, MENCH M, JACOB D and OTTE M (2010) Metal and metalloid removal in constructed wetlands, with emphasis on the importance of plants and standardized measurements: A review. Environ. Pollut. 158 3447-3461. https://doi.org/10.1016/j. envpol.2010.08.018

MIN JH and WISE WR (2009) Simulating short-circuiting flow in a constructed wetland: the implications of bathymetry and vegetation effects. Hydrol. Process. 23 830-841. https://doi. org/10.1002/hyp.7219
NIVALA J, HOOS M, CROSS C, WALLACE S and PARKIN G (2007) Treatment of landfill leachate using an aerated, horizontal subsurface-flow constructed wetland. Sci. Total Environ. 380 19-27. https://doi.org/10.1016/j.scitotenv.2006.12.030

NIVALA J, KNOWLES P, DOTRO G, GARCÍA J and WALLACE $S$ (2012) Clogging in subsurface-flow treatment wetlands: measurement, modeling and management. Water Res. $461625-$ 1640. https://doi.org/10.1016/j.watres.2011.12.051

NIVALA J and ROUSSEAU D (2009) Reversing clogging in subsurfaceflow constructed wetlands by hydrogen peroxide treatment: Two case studies. Water Sci. Technol. 59 2037-2046. https://oi. org/10.2166/wst.2009.115

OCHIENG GM, SEANEGO ES and NKWONTA OI (2010) Impacts of mining on water resources in South Africa: A review. Sci. Res. Essays 5 3351-3357.

PEDESCOLL A, CORZO A, ALVAREZ E, GARCÍA J and PUIGAGUT $J$ (2011) The effect of primary treatment and flow regime on clogging development in horizontal subsurface flow constructed wetlands: an experimental evaluation. Water Res. 45 3579-3589. https://doi.org/10.1016/j.watres.2011.03.049

SAEED T and SUN G (2012) A review on nitrogen and organics removal mechanisms in subsurface flow constructed wetlands: dependency on environmental parameters, operating conditions and supporting media. J. Environ. Manage. 112 429-448. https:// doi.org/10.1016/j.jenvman.2012.08.011

SHERIDAN C, GLASSER D and HILDEBRANDT D (2011) A calculation of the hydraulic properties of a vegetated gravel bed filter using an impulse-response tracer experiment to quantify nonideal behaviour. Proceedings of the 12th International Conference on Environmental Science and Technology. Global Network on Environmental Science and Technology, Rhodes, Greece. 1711-1716.

SHERIDAN C, HILDEBRAND D and GLASSER D (2014) Turning wine (waste) into water: toward technological advances in the use of constructed wetlands for winery effluent treatment. AIChE J. 60 420-431. https://doi.org/10.1002/aic.14297

SHERIDAN CM, GLASSER D and HILDEBRANDT D (2014) Estimating rate constants of contaminant removal in constructed wetlands treating winery effluent: A comparison of three different methods. Process Saf. Environ. Prot. 92 903-916. https://doi. org/10.1016/j.psep.2013.09.004

STEHLE S, ELSAESSER D, GREGOIRE C, IMFELD G, NIEHAUS E, PASSEPORT E, PAYRAUDEAU S, SCHÄFER RB, TOURNEBIZE J and SCHULZ R (2011) Pesticide risk mitigation by vegetated treatment systems: a meta-analysis. J. Environ. Qual. 40 1068-1080. https://doi.org/10.2134/jeq2010.0510

STOTTMEISTER U, WIEßNER A, KUSCHK P, KAPPELMEYER U, KÄSTNER M, BEDERSKI O, MÜLLER RA and MOORMANN $\mathrm{H}$ (2003) Effects of plants and microorganisms in constructed wetlands for wastewater treatment. Biotechnol. Adv. 22 93-117. https://doi.org/10.1016/j.biotechadv.2003.08.010

SULIMAN F, FRENCH H, HAUGEN L and SØVIK A (2006) Change in flow and transport patterns in horizontal subsurface flow constructed wetlands as a result of biological growth. Ecol. Eng. 27 124-133. https://doi.org/10.1016/j.ecoleng.2005.12.007

TANNER CC (1994) Growth and nutrition of Schoenoplectus Validus in agricultural wastewaters. Aquat. Bot. 47 131-153. https://doi. org/10.1016/0304-3770(94)90010-8

TANNER CC, SUKIAS JP and UPSDELL MP (1998) Organic matter accumulation during maturation of gravel-bed constructed wetlands treating farm dairy wastewaters. Water Res. 32 30463054. https://doi.org/10.1016/S0043-1354(98)00078-5

TIBANE E and VERMEULEN A (2013) Water Affairs - South Africa Yearbook 2013/2014. Department: Government Communication and Information System, South Africa, Pretoria.

VAN VUUREN L (2014) Biomimicry: Exploring nature's genius for a better tomorrow. The Water Wheel 13 (6) 12-15. Water Research Commission, Pretoria.

VYMAZAL J (2009) The use of constructed wetlands with horizontal sub-surface flow for various types of wastewater. Ecol. Eng. 35 1-17. https://doi.org/10.1016/j.ecoleng.2008.08.016 